\title{
Physical and sensory characteristics of milk and white compound chocolate added with Asian pigeonwings flower (Clitoria ternatea)
}

\author{
Puput Dwi Lestari ${ }^{1}$, Kawiji ${ }^{1}$, Anastriyani Yulviatun ${ }^{1}$, Ronny Martien ${ }^{2}$, and Dimas \\ Rahadian Aji Muhammad ${ }^{1, *}$ \\ ${ }^{1}$ Departement of Food Science and Technology, Faculty of Agriculture, Universitas Sebelas Maret, Jl. \\ Ir. Sutami 36A Kentingan, Surakarta, 57126, Jawa Tengah, Indonesia \\ ${ }^{2}$ Department of Pharmaceutics, Faculty of Pharmacy, Universitas Gadjah Mada, Jl. Sekip Utara, \\ Sinduadi, 55281, Yogyakarta, Indonesia
}

\begin{abstract}
Milk compound chocolate and white compound chocolate are confectionery products derived from cocoa that are popular worldwide, while the Asian pigeonwings flower is an herbal plant with the potential to be added to chocolate to increase the functional value of chocolate product. In this study, Asian pigeonwings flower powder was added to milk compound chocolate and white compound chocolate and evaluated its physical and sensory characteristics. The experimental design employed a completely randomized design (CRD) with one factor: the concentration of Asian pigeonwings flower powder $(0 \%, 5 \%, 10 \%$, and $15 \%)$. Physical characteristics included color and hardness, while sensory characteristics consisted of color, aroma, taste, texture, and overall, determined by a scoring preference test. The results revealed that the addition of Asian pigeonwings flower powder affected the chocolate's color and hardness and decreased the panelists' acceptance levels. In this case, further research about optimizing the formulation is needed, for example encapsulation of Asian pigeonwings flower extract in milk compound chocolate and white compound chocolate to improving physical and sensory attributes.
\end{abstract}

\section{Introduction}

Cocoa (Theobroma cacao L.) is one of the mainstay plantation commodities with an essential role in the national economy [1]. One form of processed cocoa is chocolate. Chocolate is a category of food easily digested by the body and contains many vitamins, such as vitamins A1, B1, B2, C, D, and E, and as well as minerals, such as phosphorus, magnesium, iron, and copper. Chocolate also contains antioxidants and polyphenol compounds, which are beneficial for health. In addition, the active compounds in chocolate, such as caffeine, theobromine, methyl-xanthine, and phenylethyl alanine, are believed to improve mood and reduce fatigue [2].

\footnotetext{
* Corresponding author: dimasrahadian@staff.uns.ac.id
} 
Moreover, chocolate consumption is increasing along with the globalization and people's purchasing power. Thus, product diversification or modification is needed to increase its selling power [3]. Diversification of cocoa-derived products, such as chocolate and cocoa drink, aims to produce functional products beneficial to health by adding functional compounds in the chocolate manufacturing process. It has been reported that some ingredients were added to the chocolate such as probiotics in chocolate [4], green tea and soy powder in dark chocolate [5], cinnamon powder in cocoa drink [6], lemongrass essential oil in dark chocolate [7], and encapsulated cinnamon extract in chocolate [8]. Moreover, the addition of ingredients that contain antioxidants can positively impact body health, for example, Asian pigeonwings flower. Asian pigeonwings flower contains bioactive components from the flavonoid group, such as anthocyanins [9]. Anthocyanins are a subclass of flavonoids that act as antioxidants, are water-soluble, and are responsible for the red, purple, and blue colors of fruits, vegetables, cereals, and flowers [10]. Meanwhile, the phytochemicals contained in Asian pigeonwings flower are tannins, phlobatannins, saponins, triterpenoids, carbohydrates, phenol flavonoids, flavonoids glycosides, proteins, alkaloids, anthraquinones, anthocyanin, stigmast-4-ene-3,6-dione, volatile oils, and steroids [11].

Based on this background, the addition of Asian pigeonwings flower powder to milk compound chocolate and white compound chocolate products was hypothesized to affect the panelists' acceptance levels so that it is important to carry out the physical and sensory characterization of milk compound chocolate and white compound chocolate bars. The addition of Asian pigeonwings flower powder to milk compound chocolate and white compound chocolate is expected to create a chocolate-based functional food innovation that is beneficial to human health and can be commercialized by the food industry.

\section{Materials and Methods}

The ingredients used in making Asian pigeonwings flower chocolate were milk compound chocolate and white compound chocolate with a brand of Tulip produced by PT. Freyabadi Indotama (Indonesia). Meanwhile, Asian pigeonwings flower powder was obtained from Kusuka Ubiku, Bantul, Yogyakarta. The process of making milk compound chocolate and white compound chocolate referred to previous published report with some modifications [7]. First, the chocolate was cut into small pieces to quickly melt at hot temperatures. The chocolate melting process was carried out, by the Au Bain Marie method (steam technique) [12]. The Asian pigeonwings flower powder was mixed into the melted milk compound chocolate and white compound chocolate afterward. This process utilized a Cocoa Town melanger that circulate the mixture continuously for 60 minutes. This stage aimed to produce a homogeneous chocolate dough and reduce the gritty texture of the final product $[6,13]$. Then, molding and cooling were conducted. The chocolate dough was molded and stored in the refrigerator for 15 minutes at a temperature of $5-8^{\circ} \mathrm{C}$. Milk compound chocolate and white chocolate bars were then removed from the mold and packaged using aluminum foil. This packaging aimed to protect the product from environmental influences [6].

Then, the physical analysis included color and hardness. The color test of milk compound chocolate and white compound chocolate was measured using a Konica Minolta CR-400 Chroma Meter. SCE (Specular Component Exclude) mode values were recorded, and color parameters were expressed in the CIELAB system. $\mathrm{L}^{*}$ (lightness ranging from 0 (black) to 100 (white)), $\mathrm{a}^{*}$ (green to red) and $\mathrm{b}^{*}$ (blue to yellow). The hardness test of milk compound chocolate and white compound chocolate was evaluated utilizing ASTM D 882 Universal Testing Machine Brand Zwick. The measurement of the chocolate hardness 
referred to a study Muhammad et al. [13]. In this case, hardness (N) was defined as the maximum force recorded during probe penetration into the chocolate up to product crack.

Meanwhile, sensory analysis of milk compound chocolate and white compound chocolate with four formula variations for adding Asian pigeonwings flower powder $(0 \%$, $5 \%, 10 \%$, and $15 \%$ ) was evaluated employing the scoring preference test to determine the panelists' preference for the product [14]. Sensory tests were carried out at the Sensory Laboratory, Faculty of Agriculture, UNS. Untrained panelists required for organoleptic testing of at least 30 people [15], and thus this preference test was carried out by 35 untrained panelists varying in age 20-23 years. Parameters assessed comprised color, aroma, taste, texture, and overall. Panelists were presented with four samples $(0 \%, 5 \%$, $10 \%$ and $15 \%$ ) with different codes in a single serving plate (for each milk compound chocolate and white compound chocolate). Chocolate served at room temperature (20$25^{\circ} \mathrm{C}$ ), with a weight of $6 \mathrm{~g}$ and size of $2.5 \mathrm{~cm} \mathrm{x} \mathrm{cm} \mathrm{x} 1 \mathrm{~cm}$. Panelists were given crackers and mineral water for rinsing between samples. Panelists were prohibited from comparing one sample to another. Sensory test results were known through a scoring test form, which was filled in by the panelists with a scale of 1 for strongly dislike, 2 for dislike, 3 for moderately dislike, 4 for moderately like, 5 for like, and 6 for strongly like.

Further, the experimental design used was a completely randomized design (CRD) with one factor, namely the concentration of Asian pigeonwings flower powder, so that four formulas were studied, including $0 \%, 5 \%, 10 \%$, and $15 \%$. The data from physical and sensory analysis were then analyzed employing nonparametric statistical method, namely the Friedman test. If there was a difference, then the significant discriminant test was continued using Duncan's Multiple Range Test (DMRT), with a confidence level of 95\%.

\section{Results and discussion}

\subsection{Physical Characteristics}

\subsubsection{Color}

The addition of Asian pigeonwings flower powder resulted in changes in the color properties of milk compound chocolate and white compound chocolate can be seen in Table 1.

Table 1. Color test results on milk compound chocolate and white compound chocolate with the addition of Asian pigeonwings flower powder

\begin{tabular}{|c|c|c|c|c|}
\hline \multirow{2}{*}{ Sample } & $\begin{array}{c}\text { Asian pigeonwings } \\
\text { flower powder } \\
\text { concentration }\end{array}$ & $\mathrm{L}^{*}$ & $\mathrm{a}^{*}$ & $\mathrm{~b}^{*}$ \\
\hline \multirow{3}{*}{$\begin{array}{c}\text { Milk } \\
\text { compound } \\
\text { chocolate }\end{array}$} & $0 \%(\mathrm{M} 0)$ & $34.19 \pm 0.10^{\mathrm{d}}$ & $7.84 \pm 0.09^{\mathrm{d}}$ & $12.11 \pm 0.10^{\mathrm{d}}$ \\
\cline { 2 - 5 } & $5 \%(\mathrm{M} 1)$ & $30.42 \pm 0.29^{\mathrm{c}}$ & $4.15 \pm 0.01^{\mathrm{c}}$ & $6.79 \pm 0.13^{\mathrm{c}}$ \\
\cline { 2 - 5 } & $10 \%(\mathrm{M} 2)$ & $28.55 \pm 0.08^{\mathrm{b}}$ & $2.86 \pm 0.03^{\mathrm{b}}$ & $4.92 \pm 0.07^{\mathrm{b}}$ \\
\hline \multirow{3}{*}{$\begin{array}{c}\text { White } \\
\text { compound } \\
\text { chocolate }\end{array}$} & $15 \%(\mathrm{M} 3)$ & $27.16 \pm 0.15^{\mathrm{a}}$ & $2.14 \pm 0.07^{\mathrm{a}}$ & $3.40 \pm 0.10^{\mathrm{a}}$ \\
\cline { 2 - 5 } & $0 \%(\mathrm{M} 0)$ & $85.64 \pm 0.08^{\mathrm{d}}$ & $-5.94 \pm 0.07^{\mathrm{a}}$ & $18.62 \pm 0.21^{\mathrm{d}}$ \\
\cline { 2 - 5 } & $10 \%(\mathrm{M} 2)$ & $39.02 \pm 0.57^{\mathrm{c}}$ & $1.55 \pm 0.05^{\mathrm{b}}$ & $-6.14 \pm 0.10^{\mathrm{a}}$ \\
\cline { 2 - 5 } & $15 \%(\mathrm{M} 3)$ & $29.82 \pm 0.37^{\mathrm{a}}$ & $1.60 \pm 0.14^{\mathrm{b}}$ & $-3.26 \pm 0.08^{\mathrm{c}}$ \\
\hline
\end{tabular}

Note: Numbers followed by different superscript letters in each column within the same sample indicate a significant difference at the $95 \%$ confidence level $(\alpha=0.05)$. 
The higher the concentration of Asian pigeonwings flower powder, the lower the $\mathrm{L}^{*}, \mathrm{a}^{*}$, $b^{*}$ values in milk compound chocolate. The value of $L^{*}$ ranged from 27.16-34.19. The lower the $\mathrm{L}^{*}$ value, the darker the chocolate tended to be, meaning that the higher the concentration, the darker the chocolate. Milk compound chocolate tended to be red (positive $a^{*}$ value) and yellow (positive $b^{*}$ value), along with the low concentration of Asian pigeonwings flower powder added.

In white compound chocolate with the addition of Asian pigeonwings flower powder, the $\mathrm{L}^{*}$ value ranged from 29.82-85.64. It signified that with the increasing concentration of Asian pigeonwings flower powder, the $\mathrm{L}^{*}$ value decreased, meaning that the sample had a darker brightness. It aligns with previous research which stated that the higher the concentration of Asian pigeonwings flower was added, the more intense the color intensity was [16]. The $\mathrm{a}^{*}$ value in the W0 sample tended to be greenish in color, while W1, W2, and $\mathrm{W} 3$ tended to have a reddish color. In addition, the $\mathrm{b}^{*}$ value in the W0 sample tended to be yellow, while W1, W2, W3 tended to be blue.

Furthermore, the statistical analysis results $(\alpha=0.05)$ uncovered significant differences in the color parameters $\mathrm{L}^{*}, \mathrm{a}^{*}$, and $\mathrm{b}^{*}$ in milk compound chocolate and white compound chocolate added with Asian pigeonwings flower powder. The addition of this Asian pigeonwings flower powder affected the resulting chocolate color. In this case, the concentration of anthocyanin pigments in Asian pigeonwings flower plays a role in determining color. Low concentrations of anthocyanins produce a blue color; on the contrary, it produces a red color at high concentrations, whereas, at moderate concentrations, it produces a purple color [17].

\subsubsection{Hardness}

the addition of Asian pigeonwings flower powder resulted in changes in the texture properties of milk compound chocolate and white compound chocolate can be seen on Table 2 .

Table 2. Hardness test results on milk compound chocolate and white compound chocolate with the addition of Asian pigeonwings flower powder

\begin{tabular}{|c|c|c|}
\hline Sample & $\begin{array}{c}\text { Asian pigeonwings flower } \\
\text { powder concentration }\end{array}$ & $\mathrm{F}_{\max }(\mathrm{N})$ \\
\hline \multirow{2}{*}{$\begin{array}{c}\text { Milk } \\
\text { compound } \\
\text { chocolate }\end{array}$} & $0 \%(\mathrm{M} 0)$ & $155.56 \pm 3.88^{\mathrm{b}}$ \\
\cline { 2 - 3 } & $5 \%(\mathrm{M} 1)$ & $120.91 \pm 6.90^{\mathrm{a}}$ \\
\cline { 2 - 3 } & $10 \%(\mathrm{M} 2)$ & $129.66 \pm 8.24^{\mathrm{a}}$ \\
\hline \multirow{2}{*}{$\begin{array}{c}\text { White } \\
\text { compound } \\
\text { chocolate }\end{array}$} & $15 \%(\mathrm{M} 3)$ & $163.41 \pm 5.02^{\mathrm{b}}$ \\
\cline { 2 - 3 } & $0 \%(\mathrm{~W} 0)$ & $133.26 \pm 3.72^{\mathrm{c}}$ \\
\cline { 2 - 3 } & $5 \%(\mathrm{~W} 1)$ & $120.80 \pm 0.63^{\mathrm{a}}$ \\
\cline { 2 - 3 } & $10 \%(\mathrm{~W} 2)$ & $137.92 \pm 2.28^{\mathrm{d}}$ \\
\hline
\end{tabular}

Note: Numbers followed by different superscript letters in each column within the same sample indicate a significant difference at the $95 \%$ confidence level $(\alpha=0.05)$.

The statistical analysis results showed significant differences in the hardness parameters of white compound chocolate with the addition of Asian pigeonwings flower powder $(\alpha=0.05)$. While in the milk compound chocolate samples, there was a significant difference between the sample formula for adding 5\% and 10\% Asian pigeonwings flower powder and the formula for adding $0 \%$ and $15 \%$ Asian pigeonwings flower powder. It indicated that the addition of Asian pigeonwings flower powder to chocolate affected the hardness level of the chocolate produced. Regarding this, the addition of Asian pigeonwings flower powder 
could cause particle interactions in milk compound chocolate and white compound chocolate. Furthermore, M3 and W3 chocolates had the highest hardness levels. In this study, the hardness of chocolate with the addition of $0 \%$ Asian pigeonwings flower powder had a higher F-max than chocolate with the addition of 5\% and 10\%. It is not in line with previous research which stated that the higher the Moringa leaf flour added to dark chocolate, the harder or denser the resulting chocolate [18]. In this case, the chocolate product's hardness and texture are affected by the fluctuating temperature and humidity passed during the storage period. This temperature fluctuation can cause the chocolate texture to be more brittle $[19,20]$. In addition, hardness in chocolate is influenced by particle density, particle size distribution, moisture content, sugar composition, fat content, and tempering process [23].

\subsection{Sensory Characteristics}

Sensory characteristics of milk compound chocolate and white compound chocolate with the addition of Asian pigeonwings flower powder can be seen on Table 3.

Table 3. Panelists' acceptance levels of milk compound chocolate and white compound chocolate with the addition of Asian pigeonwings flower powder

\begin{tabular}{|c|c|c|c|c|c|}
\hline Sample & Color & Aroma & Taste & Texture & Overall \\
\hline M0 & $5.29 \pm 0.62^{\mathrm{c}}$ & $4.69 \pm 0.76^{\mathrm{c}}$ & $5.34 \pm 0.77^{\mathrm{d}}$ & $5.11 \pm 0.87^{\mathrm{d}}$ & $5.31 \pm 0.76^{\mathrm{d}}$ \\
\hline M1 & $4.03 \pm 0.99^{\mathrm{b}}$ & $4.46 \pm 0.95^{\mathrm{bc}}$ & $4.60 \pm 0.88^{\mathrm{c}}$ & $4.51 \pm 0.89^{\mathrm{c}}$ & $4.57 \pm 0.82^{\mathrm{c}}$ \\
\hline M2 & $3.63 \pm 0.97^{\mathrm{ab}}$ & $4.09 \pm 1.01^{\mathrm{b}}$ & $3.83 \pm 1.20^{\mathrm{b}}$ & $3.97 \pm 1.07^{\mathrm{b}}$ & $3.94 \pm 1.08^{\mathrm{b}}$ \\
\hline M3 & $3.23 \pm 1.00^{\mathrm{a}}$ & $3.49 \pm 1.12^{\mathrm{a}}$ & $3.03 \pm 1.07^{\mathrm{a}}$ & $3.43 \pm 1.07^{\mathrm{a}}$ & $3.30 \pm 0.97^{\mathrm{a}}$ \\
\hline W0 & $5.31 \pm 0.58^{\mathrm{b}}$ & $4.97 \pm 0.79^{\mathrm{c}}$ & $5.20 \pm 0.68^{\mathrm{d}}$ & $5.17 \pm 0.75^{\mathrm{d}}$ & $5.20 \pm 0.59^{\mathrm{d}}$ \\
\hline W1 & $4.14 \pm 0.88^{\mathrm{a}}$ & $4.43 \pm 0.66^{\mathrm{b}}$ & $4.80 \pm 0.63^{\mathrm{c}}$ & $4.74 \pm 0.61^{\mathrm{c}}$ & $4.57 \pm 0.61^{\mathrm{c}}$ \\
\hline W2 & $4.11 \pm 0.99^{\mathrm{a}}$ & $4.17 \pm 0.71^{\mathrm{b}}$ & $4.00 \pm 0.94^{\mathrm{b}}$ & $4.20 \pm 0.80^{\mathrm{b}}$ & $4.06 \pm 0.73^{\mathrm{b}}$ \\
\hline W3 & $4.00 \pm 1.06^{\mathrm{a}}$ & $3.71 \pm 0.93^{\mathrm{a}}$ & $3.09 \pm 0.68^{\mathrm{a}}$ & $3.74 \pm 0.89^{\mathrm{a}}$ & $3.14 \pm 0.88^{\mathrm{a}}$ \\
\hline
\end{tabular}

Note: Numbers followed by different superscript letters in each column within the same sample indicate a significant difference at the $95 \%$ confidence level $(\alpha=0.05)$.

\subsubsection{Color}

Based on Table 3, it can be seen that the consumer acceptance level of the milk compound chocolate and white compound chocolate's color decreased with the addition of Asian pigeonwings flower powder. Statistical analysis of color parameters $(\alpha=0.05)$ revealed significant differences in the color parameters of milk compound chocolate. Thus, it can be said that the addition of Asian pigeonwings flower powder affected panelists' acceptance of the milk chocolate color parameter. Meanwhile, in white compound chocolate, there was a significant difference between the sample formula for adding $0 \%$ Asian pigeonwings flower powder and the formula for adding 5\%,10\%, and 15\% Asian pigeonwings flower powder. This condition is consistent with previous research which stated that disclosed that color parameters greatly affected the perception and judgment of panelists [21].

In addition, the highest value of the color parameter was obtained by the formula for adding $0 \%$ Asian pigeonwings flower powder, while the lowest was obtained by the formula for adding $15 \%$ Asian pigeonwings flower powder. Based on the color test results in Table 1, the addition of $0 \%$ Asian pigeonwings flower powder had a value of $\mathrm{L}^{*}=34.19$, $\mathrm{a}^{*}=7.84$, and $\mathrm{b}^{*}=12.11(\mathrm{M} 0)$ and a value of $\mathrm{L}^{*}=85.64, \mathrm{a}^{*}=-5.94$, and $\mathrm{b} *=18.62$ (W0). It signified that the milk compound chocolate preferred by the panelists was milk compound chocolate and white compound chocolate with the highest brightness, which was the reddest in milk compound chocolate, the greenest in white compound chocolate, and the 
most yellow for both types of chocolate. Concerning this, the addition of Asian pigeonwings flower powder with various concentrations affected the color of the resulting sample. It supports by previous research which stated that Asian pigeonwings flower extracts affected the color of the resulting product [16]. The higher the concentration of Asian pigeonwings flower added, the darker the resulting color intensity, indicated by a decrease in the value of $\mathrm{L}^{*}$ in Table 1 . In this case, anthocyanins are the color pigments in Asian pigeonwings flowers, and pigment concentration plays a role in determining the color of anthocyanins.

\subsubsection{Aroma}

The statistical analysis results on aroma parameters $(\alpha=0.05)$ shown in Table 3 display significant differences in milk compound chocolate and white chocolate compound added with Asian pigeonwings flower powder. Milk compound chocolate and white compound chocolate with the addition of $0 \%$ Asian pigeonwings flower was the most preferred formula by the panelists, with a value of 4.69 (M0) and 4.97 (W0). On the other hand, the sample aroma that the panelists disliked the most was the formula with the addition of $15 \%$ Asian pigeonwings flower powder, with a value of 3.49 (M3) and 3.71 (W3). The existence of significant differences between samples indicated that each sample aroma influenced the panelists' preference levels. However, it is not in accordance with several studies that have been used Asian pigeonwings flower as a natural colorant in food. Asian pigeonwings flower extract has no aroma, so that the aroma of processed food depends on the ingredients added [22]. Likewise, previous research exposed that the addition of Asian pigeonwings flower extract to cendol did not significantly affect aroma because Asian pigeonwings flower did not have a strong or unscented aroma [16].

\subsubsection{Taste}

The statistical analysis results of sensory tests $(\alpha=0.05)$ for taste parameters showed a significant difference in milk compound chocolate and white compound chocolate with the addition of Asian pigeonwings flower powder. It signified that the panelists could distinguish well the taste parameters based on the formulation of adding Asian pigeonwings flower powder to milk compound chocolate and white compound chocolate. It proved that the variation of the Asian pigeonwings flower powder addition also affected the panelists' acceptance. In this research, panelists' assessment of milk compound chocolate samples ranged from 3.03-5.34, while in white compound chocolate, it ranged from 3.09-5.20. Based on Table 3, the addition of $15 \%$ Asian pigeonwings flower powder was the least preferred by the panelists, while the addition of $0 \%$ Asian pigeonwings flower powder was the most preferred formula by the panelists. Thus, it could be stated that the addition of this Asian pigeonwings flower powder decreased the panelists' acceptance. It is because the higher the concentration of Asian pigeonwings flower powder causes the chocolate to be less sweet, and there is a bitter aftertaste when consumed, caused by polyphenol compounds. In this case, the bitter taste is the characteristic natural taste that comes from inside the chocolate. The taste comes from alkaloid components, such as theobromine, caffeine, phenolic components, pyrazine of several peptides and free amino acids, tannins, and polyphenols. The taste caused by the nature of the food can also be caused by the food itself or the process of adding other substances so that the original taste can be reduced or increased. In other words, the taste is influenced by several crucial factors, including the composition of ingredients, chemical compounds, temperature, concentration, and interactions with other flavor components [18]. 


\subsubsection{Texture}

Based on Table 3, it can be seen that there were significant differences in the milk compound chocolate and white compound chocolate samples with the addition of Asian pigeonwings flower powder $(\alpha=0.05)$. It showed that the addition of Asian pigeonwings flower powder affected the texture of the resulting chocolate. The more addition of Asian pigeonwings flower powder to milk compound chocolate and white compound chocolate tended to be less favored by the panelists because it caused the sample texture to become harder and felt gritty. Chocolate will produce a gritty perception in mouth if particle sizes in chocolate larger than $30 \mu \mathrm{m}$ [24]. Moreover, the sample with the addition of 15\% Asian pigeonwings flower powder was the least preferred sample by the panelists because it had a value of 3.43 (M3) and 3.74 (W3). Table 3 also reveals that the sample with the addition of $15 \%$ Asian pigeonwings flower powder was the sample with the highest F-max values, which were 155.56 (M3) and 133.26 (W3). It indicated that the sample with the highest level of hardness was the sample that the panelists least liked. On the other hand, the sample with the highest acceptance level regarding the texture attribute was the $0 \%$ milk compound chocolate and white compound chocolate sample, with a value of 5.11 (M0) and 5.17 (W0). In fact, good chocolate should have a smooth texture (smooth and buttery) and can melt gently and slowly in the mouth with a complex and pleasant taste. In addition, when eaten, it melts in the mouth and does not leave a hard impression [18].

\subsubsection{Overall}

In the overall parameter, the statistical analysis results exhibited that the milk compound chocolate and white compound chocolate samples with the variations the addition of Asian pigeonwings flower powder had significant differences at the significance level of $=0.05$. Based on Table 3, the panelists' acceptance levels decreased with increasing concentration of the addition of Asian pigeonwings flower powder. The formula with the addition of $0 \%$ Asian pigeonwings flower powder was the most preferred formula by the panelists, with a value of 5.31 (M0) and 5.20 (W0). Meanwhile, the formula that the panelists disliked the most was the formula with the addition of $15 \%$ Asian pigeonwings flower powder, with a value of 3.30 (M3) and 3.14 (W3). In this case, the parameters of color, aroma, taste, texture and overall were the parameters that most influenced the panelists' acceptance because they had significant differences between the samples.

\section{Conclusion}

Based on this study's results, it was concluded that the addition of Asian pigeonwings flower powder to milk compound chocolate and white compound chocolate affected physical attributes: color and hardness, and had a significant difference $(\alpha=0.05)$. In addition, on all parameters (color, aroma, taste, texture and overall), the most formula preferred by the panelists was the formula with the addition of $0 \%$ Asian pigeonwings flower powder. Therefore, this study's results can provide additional information in developing the cocoa agroindustry in Indonesia, especially developing milk compound chocolate and white compound chocolate with the addition of Asian pigeonwings flower powder. Moreover, further research about optimizing the formulation is needed, for example encapsulation of Asian pigeonwings flower extract in milk compound chocolate and white compound chocolate to improving physical and sensory quality attributes. 


\section{References}

1. D. Praseptiangga, J.M.G. Zambrano, A.P. Sanjaya, D.R.A. Muhammad, D. R. A. AIMS Agric, Food, 5, 1 (2020)

2. J. Spillane. Komoditi Kakao, Peranannya dalam Perekonomian Indonesia. (Kasinus, Yogyakarta, 1995)

3. A.R. Ariyanto, C. Anam., Kawiji., S. Minardi., F. Zulfa, D. Purnomo, E. Muzayana, R.P. Atmaja, C. Widiatmoko, J. of Community Empower and Serv, 3, 2 (2019)

4. Yonejima, Yasunori, K. Hisa, M. Kawaguchi, H. Ashitani, T. Koyama, Y. Usamikrank, N.Kishida, S. Kishino, J. Ogawa. Biocatal. and Agric. Biotechnol. 4, (2015)

5. Y. Ikrawan, Hasnelly, D. Syahrudin. Semin. Nas. Perhimpun. Ahli Teknol. Pangan Indones. Bandar Lampung 10, 11 (2017)

6. D.R.A. Muhammad, J.E. Kongor, K. Dewettinck, K. J Food Sci. Technol. 5810 (2021).

7. A.E. Pratiwy, I Kusumaningrum, Aminullah. J. Pertan. 10, 2 (2019)

8. D.R.A. Muhammad, E. Tuenter, G.D. Patria, K. Foubert, L. Pieters, K. Dewettinck, Food Chem. 340, 127983 (2021).

9. A.M. Marpaung. J Funct. Food and Nutraceutical 1, 2 (2020)

10. P. Purwaniati, A. R. Arif, and A. Yuliantini. J. Farmagazine 7, 1 (2020)

11. E.C. Purba. J. EduMatSains, 4, 2 (2020)

12. Sugeng. Tips dan Trik Menghias Kue dengan Cokelat. (PT Kawan Pustaka, Jakarta, 2008)

13. D.R.A. Muhammad, V. Lemarcq, E. Alderweireldt, P. Vanoverberghe, D. Praseptiangga, J.G. Juvinal, K. Dewettinck. J. of Food Sci and Technol. (2019)

14. D. Setyaningsih, A. Apriyantono, M.P. Sari. Analisis Sensori (IPB Press, Bogor, 2010)

15. Badan Standarisasi Nasional. Petunjuk Pengujian Organoleptik dan atau Sensori SNI 01-2346-2006.

16. A. Fizriani, A.A. Quddus, H. Hariadi. J. Ilm Pangan dan Has. Pertan. 4, 2 (2020)

17. F. G. Winarno. Kimia Pangan \& Gizi (Pustaka Utama, Jakarta, 2007)

18. F. Rahmawati. (2016). J. Penelit. Tugas Akhir UNPAS (2016)

19. Misnawi. Pelita Perkeb. a Coffee and Cocoa Res. J. 27, 3 (2011)

20. L.M. Andrae-Nightingale, S.Y. Lee, J.E. Nicki. J. of Texture Stud. 40, (2009)

21. G. Morrot, F. Brochet, D. Dubourdieu. Brain and Lang. 79, 2 (2001)

22. R. Melati, N.S. Rahmadani. Pros. Sem. Nas. Agribisnis. (2020)

23. A.D. Saputro, D.V. de Walle, R.P. Aidoo, M.A. Mensah, C. Delbaere, N.D. Clercq, J.V. Durme, and K.Dewettinck. Eur Food Res Technol. 243, 2 (2016)

24. E.O. Afoakwa, A. Paterson, M. Flower, J.Vieira. Eur Food Res Technol. 227, 4 (2008) 